\title{
Development of transient peanut allergy following lung transplantation: A case report
}

\author{
Sacha Bhinder MD, Matthew J Heffer MD, Jason K Lee MD, Cecilia Chaparro MD, Susan M Tarlo MBBS FRCPC
}

\author{
S Bhinder, MJ Heffer, JK Lee, C Chaparro, SM Tarlo. Development \\ of transient peanut allergy following lung transplantation: A case \\ report. Can Respir J 2011;18(3):154-156.
}

A 47-year-old woman underwent bilateral lung transplantation for nonspecific interstitial pneumonitis and received donor lungs from a 12-year-old patient with a known peanut allergy. Post-transplant, the patient experienced four anaphylaxis-like reactions. A skin prick test to peanut was initially positive; however, it steadily declined over serial assessments and reverted to negative one year post-transplant. The patient subsequently had a negative oral peanut challenge. Transfer of food allergy post-transplantation is theorized to occur via transfer of donor B lymphocytes producing peanut-specific immunoglobulin $\mathrm{E}$ into the circulation of the recipient. An alternate mechanism proposes passive transfer of immunoglobulin E-sensitized mast cells and/or basophils within the transplanted tissue that subsequently migrate into recipient tissues. The gradual decline in the magnitude of the peanut skin prick test and its return to negative over the course of one year supports the gradual depletion of sensitized cells in the recipient (B lymphocytes and, possibly, mast cells), and supports the initial passive transfer of sensitized cells from donor tissue during transplantation. This should be considered when donor organs are obtained from allergic individuals.

Key Words: Anaphylaxis; Basophil; Lung transplantation; Mast cell; Peanut

Deanut allergy is one of the most common food-related allergies, with a lifetime prevalence of $1.5 \%$ in the United States population (1). At a population level, anaphylaxis has been reported to have an incidence ranging between 3.2 per 100,000 person-years and 20 per 100,000 person-years, of which anaphylaxis to ingested foods accounts for $33 \%$ of these cases (2). In the United States, peanut anaphylaxis accounts for an estimated 15,000 emergency room visits per year and nearly 100 deaths (3).

Anaphylaxis is an immunoglobulin (Ig) E antibody-mediated mast cell and/or basophil-dependent process that results in degranulation of mast cells and/or basophils and the release of vasoactive and proinflammatory compounds $(4,5)$. Mast cells are distributed throughout connective tissue and are found adjacent to blood and lymphatic vessels (6), while basophils are present in the blood. The distribution of mast cells and basophils, and the resulting release of intracellular compounds with relevant allergen exposure, can culminate in anaphylaxis and multisystem involvement leading to any combination of cardiovascular, respiratory, gastrointestinal and/or dermatological manifestations.

In the setting of transplantation, transfer of food allergy has been previously reported. One case lost peanut allergy following bone marrow transplantation (7), while other cases have acquired the specific allergy of the donor after bone marrow transplant (8-11) or liver transplantation $(12,13)$. The nature of these transplants involves transfer of pluripotent hematopoietic stem cells and mature donor lymphocytes into recipient tissues. Transfer of donor T helper $2 \mathrm{~B}$ lymphocytes producing specific IgE antibodies in recipient tissue can result in ongoing cellular and humoral activity against the allergen. Transferred cell populations are not deleted by post-transplant immunosuppression.

\author{
Un rapport de cas d'apparition d'allergie transitoire \\ aux arachides après une transplantation pulmonaire
}

Une femme de 47 ans a subi une transplantation pulmonaire bilatérale en raison d'une pneumonite interstitielle non spécifique et a reçu les poumons d'un patient de 12 ans ayant une allergie connue aux arachides. Après la transplantation, la patiente a vécu quatre réactions d'apparence anaphylactique. Un test d'intradermoréaction aux arachides a d'abord été positif, mais il s'est atténué régulièrement dans le cadre d'évaluations sérielles et est redevenu négatif un an après la transplantation. La patiente a ensuite obtenu une provocation orale négative aux arachides. En théorie, une allergie alimentaire peut se produire par transfert des lymphocytes B du donneur, entraînant la présence d'immunoglobuline E propre aux arachides dans la circulation du receveur. On postule aussi qu'un autre mécanisme produirait un transfert passif des mastocytes ou des basophiles sensibilisés à l'immunoglobuline $\mathrm{E}$ dans les tissus transplantés qui migrent ensuite dans les tissus du receveur. La diminution graduelle de la réaction au test d'intradermoréaction et l'obtention de résultats négatifs au bout d'un an étayent la déplétion graduelle des cellules sensibilisées du receveur (les lymphocytes $B$ et peut-être les mastocytes), de même que le transfert passif initial des cellules sensibilisées des tissus du donneur pendant la transplantation. Il faudrait en tenir compte à l'obtention d'organes provenant de personnes allergiques.

Transfer of peanut allergy following lung transplantation has been previously reported only once (14). The case involved transplantation of donor lungs from a 12-year-old boy (who died from peanut anaphylaxis) into a 42-year-old recipient. Given the histology of lung tissue, lung transplantation results in limited transfer of pluripotent hematopoietic cells and mature lymphocytes into recipient tissues. As a result, the mechanism of allergy transfer following lung transplantation was postulated to involve passive transfer of IgE-sensitized donor mast cells within the transplanted lung into the recipient.

\section{CASE PRESENTATION}

The present case involved a 47-year-old woman diagnosed with nonspecific interstitial pneumonitis in 2006, who subsequently underwent bilateral lung transplantation in January 2008. The donor lungs were obtained from a 12-year-old boy who died of anoxic brain injury secondary to an obstructed ventriculoperitoneal shunt. The donor was known to have a history of peanut allergy; however, did not have a history of peanut anaphylaxis and his death was unrelated to peanut exposure.

The recipient had a history of generalized urticaria to shellfish (which she therefore avoided), mild perennial allergic rhinitis to dust exposure, and mild seasonal allergic rhinitis related to grass pollen exposure for which she had received grass pollen immunotherapy treatment from 27 to 37 years of age. She had no history of peanut or tree nut allergy, and no history of anaphylaxis.

In the post-transplantation setting, the recipient experienced four anaphylactic episodes involving generalized flushing, pruritis, dyspnea and hypotension without evidence of urticaria or angioedema. These episodes occurred over a four-week period following her surgery. The first episode occurred while in hospital after consuming a commercial 
breakfast cereal; the episode resolved within $2 \mathrm{~h}$. The second and third episode were following hospital discharge, after consumption of a commercially prepared coconut cream pie. A fourth episode occurred after consumption of a commercial chocolate bar with almonds. This latter episode required emergency room treatment with adrenaline and diphenhydramine. While no single episode clearly involved peanut consumption, none of the ingested products were certified to be peanut free. Post-transplantation, the immunosuppressive regimen for the patient involved azathioprine and cyclosporine, but did not include tacrolimus, which has been associated with development of food allergy (15).

Initial skin prick testing in March 2008 revealed a 3+ $(7 \mathrm{~mm} \times 8 \mathrm{~mm})$ wheal to peanut allergen and a $2+$ response to pine nut (both $1 / 10$ weight per volume dilutions in $50 \%$ glycerin preservative, supplied by Omega, Canada). No other tree nut allergen extracts elicited a positive response. Despite the history of coconut exposure preceding two of the anaphylaxis-like events, skin prick testing and subsequent oral challenge to coconut was negative, indicating that cross-contamination of the coconut-containing products with peanut was probably responsible for the anaphylaxis-like reactions. Additionally, complete blood counts did not demonstrate eosinophilia. Total serum IgE was not measured; however, serum drawn from the patient on the day she presented for skin prick testing was submitted for radioallergosorbent testing (RAST) for peanut-specific $\operatorname{IgE}$ and was negative (lower than $0.35 \mathrm{kU} / \mathrm{L}$ ), demonstrating the absence of measurable circulating peanut-specific IgE antibodies.

Through follow-up and serial skin prick testing to peanut allergen, the positive response to peanut skin prick testing steadily declined over the course of nine months and reverted to negative in January 2009 , approximately one year post-transplant. An oral peanut challenge performed in a controlled setting in August 2009 was negative.

\section{DISCUSSION}

Instances of bone marrow transplant recipients developing allergic disease similar to that of their donors have been known since the 1980s. In 1988, Agosti et al (11) reported that recipients undergoing bone marrow transplantation from donors with allergic disease formed allergen-specific IgE after transplantation. In this setting, transferred donor lymphocytes produced allergen-specific $\operatorname{IgE}$ within recipients. As part of a long-term cohort study, Hallstrand et al (16) demonstrated persistence of symptomatic allergy for up to 14 years post-transplant.

However, for transient cases of anaphylaxis occurring only shortly after transplantation, it has been postulated that passive transfer of donor mast cells or basophils sensitized by donor peanut-specific IgE occurred from donor to recipient via transplanted tissues (17).

Given that lung tissue harbours approximately 600,000 mast cells per gram of tissue (18), and transplanted tissue is capable of transferring an immunological phenotype, the mechanism of allergy transfer proposed by Castells and Boyce (17) could explain transferred airway allergic responses. However, because mast cells are tissue based and not well documented as being capable of migration to other organs, it would be difficult to explain transferred food allergy on this basis. It is more likely that the effects experienced by this patient were caused by transfer of sensitized B lymphocytes (and possibly basophils), resulting in specific IgE production and sensitization of recipient mast cells, resulting in transient peanut allergy. Accordingly, the patient in the present report had no significant respiratory symptoms during her anaphylactic episodes, suggesting that lung mast cells did not significantly participate in the response. This mechanism of B lymphocyte transfer and specific IgE production was also more likely in the present patient because she had a positive skin test response, and it is not known whether sensitized mast cells or basophils would migrate from lung tissue or blood into the skin.

While free serum IgE is known to have a half-life of two to four days, mast cell-bound IgE has a considerably longer half-life, which was elegantly demonstrated by Walzer and Brunner (19). They injected patients intradermally with serum from patients allergic to fish. Injected patients were then fed fish and an urticarial response at the site of injection was noted. Walzer and Brunner noted that this urticarial response could be replicated for up to six months, thus demonstrating that IgE-sensitized mast cells can persist for some time and result in symptomatic allergy. However, in the setting of plasma transfusion, persistence of symptomatic allergy has been demonstrated for less than two months (20). While the half-life of mast cell-bound IgE is considerably longer than that of free serum IgE, the persistence of symptomatic allergy stemming from mast cell-bound IgE is likely considerably variable.

In the present case, a negative peanut RAST indicated an absence of measurable serum peanut-specific IgE and suggested low, if any, ongoing active production of peanut-specific IgE antibody to the peanut allergens assessed in the RAST approximately two months post-transplant. However, a positive skin prick test to peanut allergen supports the presence of tissue mast cells sensitized by peanut-specific IgE antibody.

The passive transfer of allergen-sensitized mast cells, basophils or $\mathrm{T}$ helper $2 \mathrm{~B}$ lymphocytes during organ transplantation can result in anaphylaxis for transplant recipients. Additionally, lack of anaphylaxis history from the organ donor does not exclude the possibility of organ recipients experiencing anaphylaxis. Obtaining a detailed donor allergy history may help to identify transplant recipients that are at higher risk of experiencing post-transplant anaphylaxis. It is prudent for transplant recipients to consider avoiding food allergens to which the donor had allergic responses in an effort to reduce the risk of experiencing anaphylaxis. In the post-transplantation setting, there may be a role for skin prick testing of individuals who received organs from donors with a known history of anaphylaxis or severe allergy to predict recipients who are at a greater risk of experiencing anaphylaxis. Additionally, in the event of an allergic or anaphylactic reaction, an attempt by the patient, caregiver or physician should be made to obtain a sample of the food product(s) suspected to be responsible for the reaction to guide further allergy testing.

DISCLOSURE: The authors have no financial disclosures or conflicts of interest to declare.

\section{REFERENCES}

1. Sicherer SH, Munoz-Furlong A, Sampson HA. Prevalence of peanut and tree nut allergy in the United States determined by means of a random digit dial telephone survey: A 5-year follow-up study. J Allergy Clin Immunol 2003;112:1203-7.

2. Decker WW, Campbell RL, Manivannan V, et al. The etiology and incidence of anaphylaxis in Rochester, Minnesota: A report from the Rochester Epidemiology Project. J Allergy Clin Immunol 2008; 122:1161-5.

3. American Academy of Allergy, Asthma \& Immunology. Allergy \& Asthma Advocate, 2003.

4. Lemon-Mule H, Nowak-Wegrzyn A, Berin C, Knight AK. Pathophysiology of food-induced anaphylaxis. Curr Allergy Asthma Rep 2008;8:201-8.

5. Mukai K, Obata K, Tsujimura Y, Karasuyama H. New insights into the roles for basophils in acute and chronic allergy. Allergol Int 2009;58:11-9.

6. Jahanyar J, Koerner MM, Loebe M, Youker KA, Torre-Amione G, Noon GP. The role of mast cells after solid organ transplantation. Transplantation 2008;85:1365-71.

7. Hourihane JO, Rhodes HL, Jones AM, Veys P, Connett GJ. Resolution of peanut allergy following bone marrow transplantation for primary immunodeficiency. Allergy 2005;60:536-7.

8. Saarinen UM. Transfer of latent atopy by bone marrow transplantation? A case report. J Allergy Clin Immunol 1984;74:196-200.

9. Tucker J, Barnetson RS, Eden OB. Atopy after bone marrow transplantation. Br Med J (Clin Res Ed) 1985;290:116-7.

10. Walker SA, Riches PG, Wild G, et al. Total and allergen-specific $\mathrm{IgE}$ in relation to allergic response pattern following bone marrow transplantation. Clin Exp Immunol 1986;66:633-9.

11. Agosti JM, Sprenger JD, Lum LG, et al. Transfer of allergen-specific IgE-mediated hypersensitivity with allogeneic bone marrow transplantation. N Engl J Med 1988;319:1623-8. 
12. Legendre C, Caillat-Zucman S, Samuel D, et al. Transfer of symptomatic peanut allergy to the recipient of a combined liver-and-kidney transplant. N Engl J Med 1997;337:822-4.

13. Phan TG, Strasser SI, Koorey D, et al. Passive transfer of nut allergy after liver transplantation. Arch Intern Med 2003;163:237-9.

14. Khalid I, Zoratti E, Stagner L, Betensley AD, Nemeh H, Allenspach L. Transfer of peanut allergy from the donor to a lung transplant recipient. J Heart Lung Transplant 2008;27:1162-4.

15. Ozdemir O, Arrey-Mensah A, Sorensen RU. Development of multiple food allergies in children taking tacrolimus after heart and liver transplantation. Pediatric Transplant 2006;10:380-3.

16. Hallstrand TS, Sprenger JD, Agosti JM, Longton GM, Witherspoon RP, Henderson WR. Long-term acquisition of allergen-specific IgE and asthma following allogeneic bone marrow transplantation from allergic donors. Blood 2004;104:3086-90.

17. Castells M, Boyce J. Transfer of peanut allergy by a liver allograft. N Engl J Med 1998;338:202-3.

18. Coleman JW, Godfrey RC. The number and affinity of IgE receptors on dispersed human lung mast cells. Immunology 1981;44:859-63.

19. Walzer M, Brunner M. Absorption of undigested proteins in human beings: Absorption of unaltered fish proteins in adults.

Arch Intern Med 1928;42:172-9.

20. Arnold DM, Blajchman MA, DiTomasso J, Kulczycki M, Keith PK. Passive transfer of peanut hypersensitivity by fresh frozen plasma. Arch Intern Med 2007;167:853-4. 


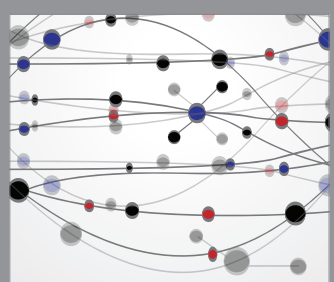

The Scientific World Journal
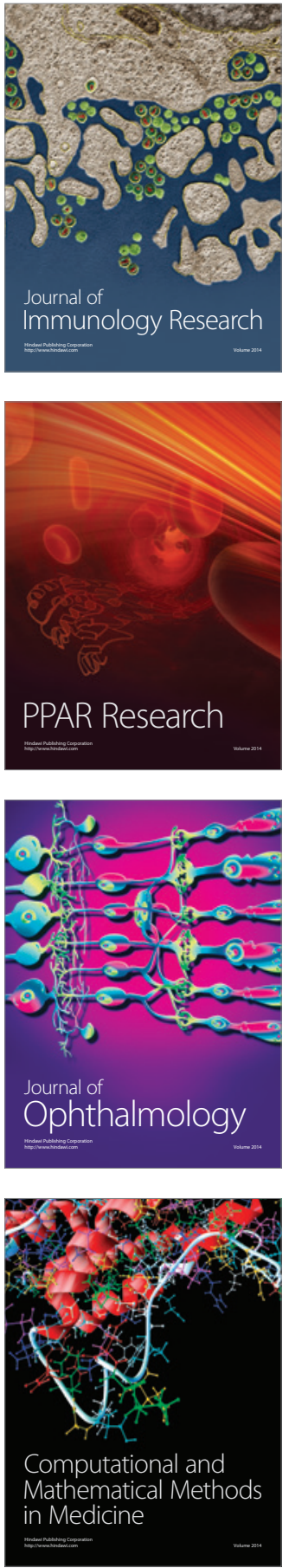

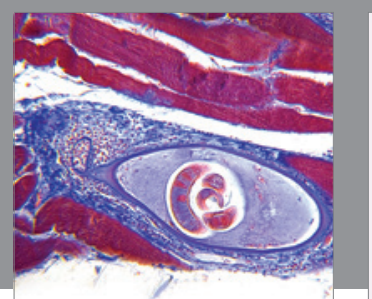

Gastroenterology Research and Practice

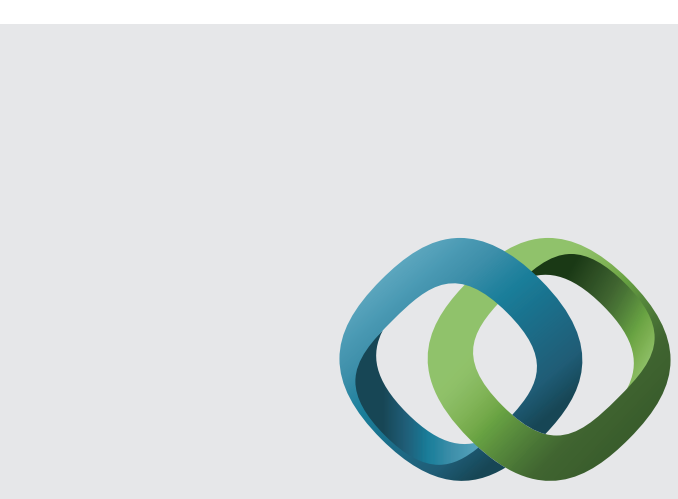

\section{Hindawi}

Submit your manuscripts at

http://www.hindawi.com
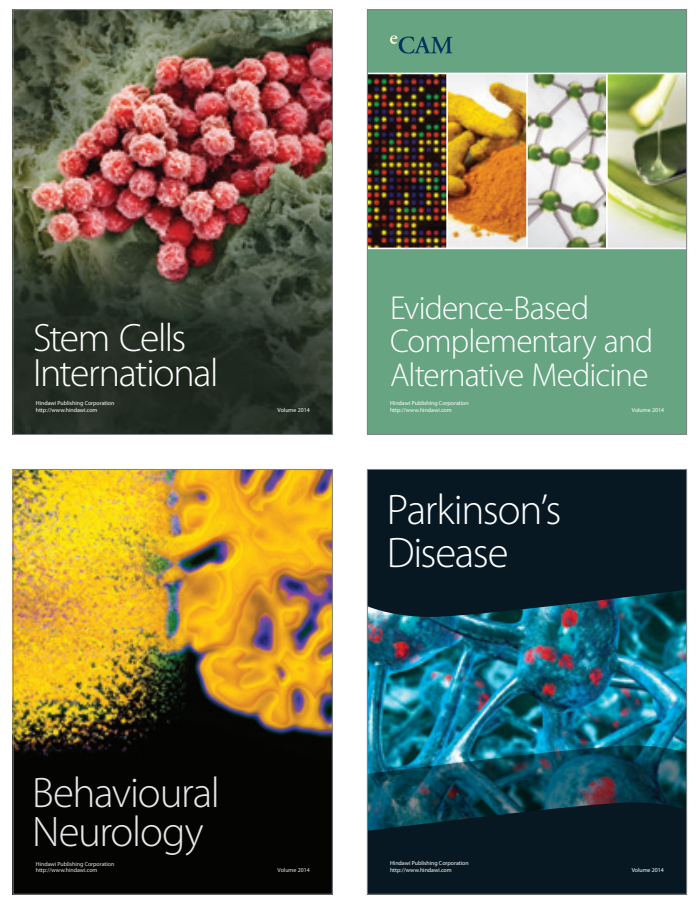
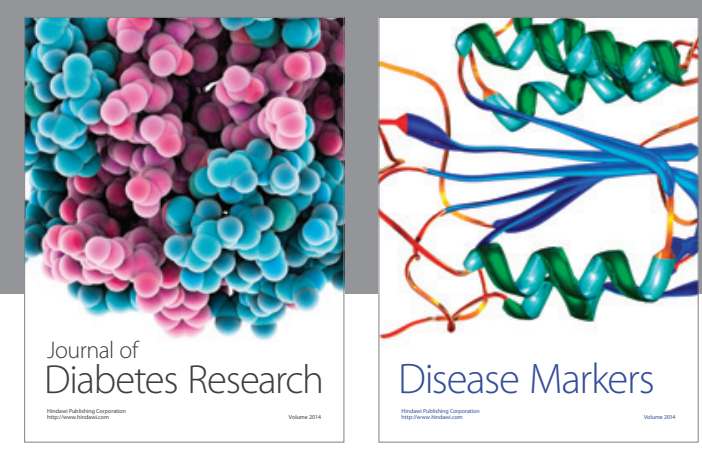

Disease Markers
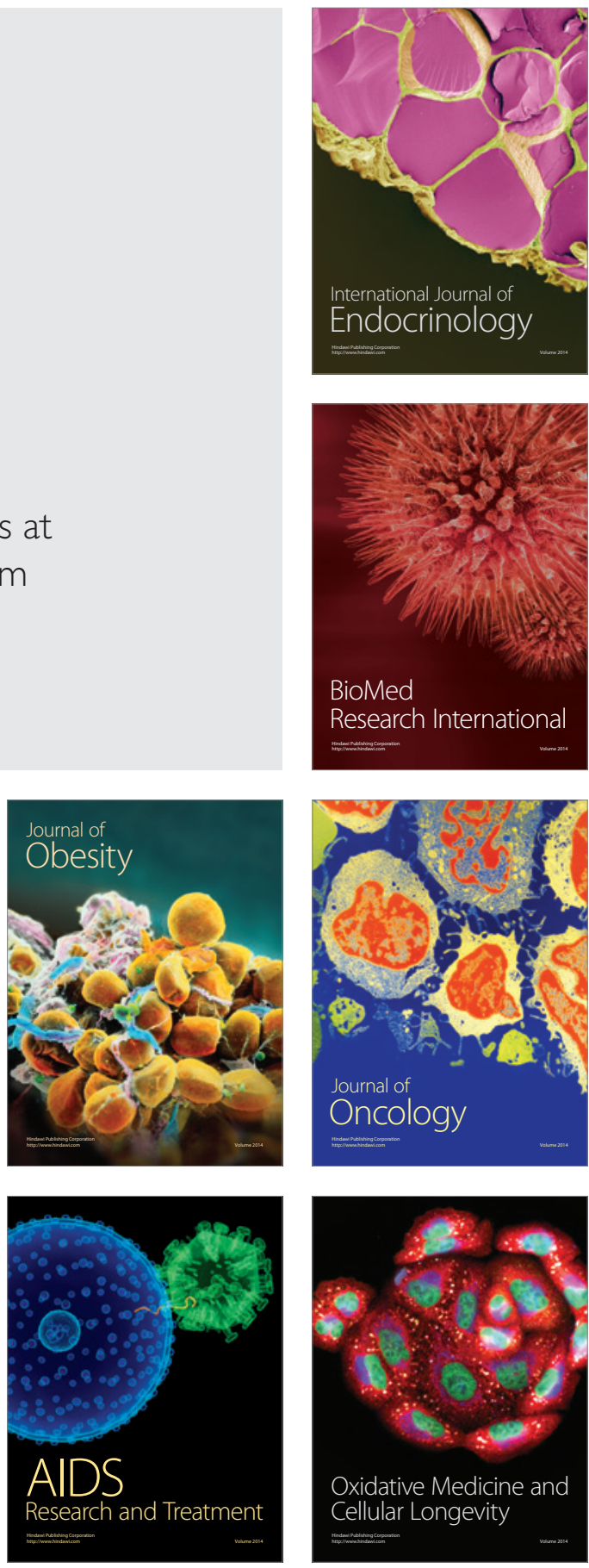